\title{
Role of Spexin and Leptin in Obesity Among Male Pakistani Population
}

\author{
Mussarat Ashraf ${ }^{1}$, Sher Khan ${ }^{1}$ and Rabiya Ali²* \\ ${ }^{1}$ Department of Biological \& Biomedical Sciences, Aga Khan University, Karachi, Pakistan \\ ${ }^{2}$ Department of Physiology, Karachi Institute of Medical Sciences, Karachi, Pakistan
}

\section{Respected Editor,}

There is an increased prevalence of obesity with an off shoot of metabolic disorders in our part of the world. Obesity is considered as a leading complex disorder that has increased worldwide at shocking speed affecting mankind including Pakistan [1]. The metabolic changes accompanying obesity are insulin resistance, glucose intolerance, hyperleptinemia and chronic inflammation.

Leptin, a protein hormone comprising of 167 amino acids with a weight of $16 \mathrm{kDa}$, coded by leptin gene LEP A19G is secreted by the cells of adipose tissues. Leptin performs various roles in the human body, for instance the regulation of appetite, energy homeostasis, and neuroendocrine function [2]. Leptin being an imperative regulator of the mass of adipose tissue is thus a major factor for obesity and insulin resistance in the human body.

Spexin discovered by Mirabeau et al. in 2007 is a novel peptide expressed in human endocrine and epithelial tissues [3]. Spexin is expressed by orf39 gene located at the chromosome number 12 in several body tissues. A few studies explored the potential role of Spexin as a biomarker of insulin resistance and obesity thus recognizing it as a possible shielding factor confronting progress of obesity. It has been observed that Spexin and Leptin both have a paradoxical effect. We conducted a pilot study in male subjects; analyzed Leptin and Spexin by ELISA according to manufacturer's kit manual and found their association with BMI and Body fats. Leptin and Spexin have been observed to exhibit opposite correlation with obesity. Table 1 shows the spearman's correlation of Spexin and Leptin with BMI \& Body fats. We observed a positive correlation between Leptin with BMI \& Body fats. (rho value $=0.519, p<0.001 \&$ rho value $=0.464, p<0.001$ ), no statistical correlation was found between Spexin with $\mathrm{BMI}$ and fats. However, inadequate relation between circulating Spexin and Leptin levels has been detected to date. So, there is a need to investigate the role of Spexin on large number of individuals with obesity. In future studies, if the statistical link is established on larger number of subjects between elevated serum level concentration of Spexin and reduction in obesity, we can propose the use of Spexin as a therapeutic measure to overcome obesity [4]. There is also a need to investigate the genetic cause of Leptin and Spexin with reference to obesity that can help us to explore new ways to confront with the challenging disorder of obesity development.

Table 1: Correlation of Spexin and Leptin with study variables.

\begin{tabular}{c|c|c|c|c|c|c|c|c}
\hline \multicolumn{2}{c|}{$\begin{array}{c}\text { Spearman's Rho } \\
\text { Variables }\end{array}$} & $\begin{array}{c}\text { Age } \\
\text { (Years) }\end{array}$ & $\begin{array}{c}\text { BMI } \\
(\mathbf{k g} / \mathbf{m} 2)\end{array}$ & $\begin{array}{c}\text { Body Fat } \\
\mathbf{( \% )}\end{array}$ & $\begin{array}{c}\text { CHO2L } \\
\text { (mg/dl) }\end{array}$ & $\begin{array}{c}\text { TRIGL } \\
\text { (mg/dl) }\end{array}$ & $\begin{array}{c}\text { LDLC3 } \\
\text { (mg/dl) }\end{array}$ & $\begin{array}{c}\text { HDLC4 } \\
\text { (mg/dl) }\end{array}$ \\
\hline \multirow{2}{*}{$\begin{array}{c}\text { Spexin } \\
(\mathrm{ng} / \mathrm{m}) \\
\mathrm{n}=44\end{array}$} & rho value & 0.164 & -0.057 & 0.05 & 0.071 & -0.028 & 0.041 & 0.16 \\
\cline { 2 - 9 } & p-value & 0.124 & 0.6 & 0.963 & 0.511 & 0.796 & 0.705 & 0.135 \\
\hline $\begin{array}{c}\text { Leptin } \\
(\mathrm{ng} / \mathrm{ml}) \\
\mathrm{n}=44\end{array}$ & rho value & 0.006 & 0.519 & 0.464 & 0.143 & 0.055 & 0.142 & 0.151 \\
\cline { 2 - 9 } & p-value & 0.953 & $<0.001^{*}$ & $<0.001^{*}$ & 0.181 & 0.612 & 0.186 & 0.161 \\
\hline
\end{tabular}

Where: CHO2L (Cholesterol), TRIGL (Triglyceride), HDLC4 (High Density Lipoprotein), LDLC3 (Low Density Lipoprotein), BMI (Body Mass Index). *shows statistical significe at $p$ value $<0.05$ (Spearman's Rank Correlation was applied)

\section{CONFLICT OF INTEREST}

The authors declare no conflict of interest.

*Corresponding Author: Rabiya Ali, Department of Physiology, Karachi Institute of Medical Sciences, Karachi, Pakistan;

Email: rabiya.rehan@gmail.com

Received: May 29, 2020; Revised: June 20, 2020; Accepted: July 16, 2020 DOI: https://doi.org/10.37184/lnjpc.2707-3521.2.2

\section{ACKNOWLEDGEMENTS}

We would like to acknowledge Dr. Rehana Rehman and Muhammad Hassan Raza raja for their tremendous support in finalization of this study. 


\section{REFERENCES}

1. Khan AH, Fatima SS, Raheem A, Jafri L. Are serum leptin levels predicted by lipoproteins, vitamin $\mathrm{D}$ and body composition? World J Diabetes 2019; 10(4): 260.

2. Amjad S, Baig M, Zahid N, Tariq S, Rehman R. Association between leptin, obesity, hormonal interplay and male infertility. Andrologia 2019; 51(1): e13147.
3. Lv S-Y, Zhou Y-C, Zhang X-M, Chen W-D, Wang Y-D. Emerging roles of NPQ/spexin in physiology and pathology. Front Pharmacol 2019; 10: 457.

4. Bitarafan V, Esteghamati A, Azam K, Yosaee S, Djafarian K. Comparing serum concentration of spexin among patients with metabolic syndrome, healthy overweight/obese, and normal-weight individuals. Medical J Islam Repub Iran 2019; 33: 93. 